\title{
Circular and long non-coding RNAs and their role in ophthalmologic diseases
}

\author{
Olga Wawrzyniak1, Żaneta Zarębska², Katarzyna Rolle ${ }^{2,3 凶}$ and Anna Gotz-Więckowska1 ${ }^{\bowtie}$ \\ 'Department of Ophthalmology, Poznan University of Medical Sciences, Poznań, Poland; 2Department of Molecular Neurooncology, Institute \\ of Bioorganic Chemistry of the Polish Academy of Sciences, Poznań, Poland; ${ }^{3}$ Centre of Advanced Technologies, Adam Mickiewicz University, \\ Poznań, Poland
}

Long non-coding RNAs are >200-nucleotide-long RNA molecules which lack or have limited protein-coding potential. They can regulate protein formation through several different mechanisms. Similarly, circular RNAs are reported to play a critical role in post-transcriptional gene regulation. Changes in the expression pattern of these molecules are known to underlie various diseases, including cancer, cardiovascular, neurological and immunological disorders (Rinn \& Chang, 2012; Sun \& Kraus, 2015). Recent studies suggest that they are differentially expressed both in healthy ocular tissues as well as in eye pathologies, such as neovascularization, proliferative vitreoretinopathy, glaucoma, cataract, ocular malignancy or even strabismus (Li et al., 2016). Aetiology of ocular diseases is multifactorial and combines genetic and environmental factors, including epigenetic and non-coding RNAs. In addition, disorders like diabetic retinopathy or age-related macular degeneration lack biomarkers for early detection as well as effective treatment methods that would allow controlling the disease progression at its early stages. The newly discovered non-coding RNAs seem to be the ideal candidates for novel molecular markers and therapeutic strategies. In this review, we summarized the current knowledge about gene expression regulators - long non-coding and circular RNA molecules in eye diseases.

Key words: ophthalmologic diseases, neovascularization, retinopathy, AMD, ocular malignancy, long non-coding RNAs, circRNAs

Received: 28 June, 2018; revised: 28 September, 2018; accepted: 05 October, 2018; available on-line: 15 November, 2018

e-mail: kbug@ibch.poznan.pl (KR); a.gotzwieckowska@gmail.com (AGW)

Abbreviations: ADARs, adenosine deaminases acting on RNA; AGA, Amadori-glycated albumin; AMD, age-related macular degeneration; A-to-I, adenosine to inosine; CDKN2B-AS1, cyclin-dependent kinase inhibitor $2 \mathrm{~B}$ antisense non-coding RNA; circRNA, circular $\mathrm{RNA}$; CN, corneal neovascularization; CNV, choroidal neovascularization; CRYBB2, Crystallin Beta B2; DR, Diabetic retinopathy; ecircRNA, exonic circRNA; ElciRNAs, exonic, exon-intron; EMT, endothelial-mesenchymal transition; EMT, epithelial-mesenchymal transition; EOMs, extraocular muscles; ERM, epiretinal membrane; FXS, Fragile X syndrome; GAS5, Growth Arrest Specific 5; GFS, glaucoma filtration surgery; GTF; glaucoma Tenon's capsule fibroblasts; HRECs, human retinal endothelial cells; IL-1 $\beta$, interleukin- $1 \beta$; IL- 6 , interleukin-6; iNOS, Nitric Oxide Synthases isoform; IOP, increased intraocular pressure; IRESs, internal ribosome entry sites; LECs, lens epithelial cells; lincRNAs, long intergenic RNAs; IncRNA, long noncoding RNA; m6A, N6- methyladenosine; MALAT1, metastasis-associated lung adenocarcinoma transcript 1; MAPK, mitogen-activated protein kinase; MCP-1, monocyte chemotactic protein-1; MIAT, Myocardial infarction associated transcript; miRNA, microRNAs; MBL/MBNL1, Muscleblind-Like/Muscleblind Like Splicing Regulator 1 ; NF-кB, nuclear factor $\mathrm{\kappa B}$; Nrf2, nuclear factor 2; NTG, normal tension glaucoma; PANDAR, promoter of CDKN1A antisense DNA damage-activated RNA, PCO, Posterior capsule opacification; PDGF, Platelet-Derived Growth Factor; PDR, proliferative diabetic retin- opathy; PIncRNA-1, prostate cancer-up-regulated long noncoding RNA 1; POAG, primary open angle glaucoma; PRC2; polycomb repressive complex 2; pre-mRNA, pre-messenger RNA; PVR, Proliferative vitreoretinopathy; QKI protein, Quaking protein; RBPs, RNA binding proteins; RCA, rolling circle amplification; RNCR2, retinal ncRNA 2; RNCR3, retinal ncRNA3; ROP, retinopathy of prematurity; RPE, retinal pigment epithelial; SORF, small open reading frame; SOX2OT, SOX2 overlapping transcript; STAT3, signal transducer and activator of transcription 3; TGF $\beta 1$, transforming growth factor $\beta 1$; TGF $\beta 2$, transforming growth factor $\beta 2$; THOR, testis-associated highly conserved oncogenic InCRNA; TNFa, tumour necrosis factoralpha; VEGF, Vascular Endothelial Growth Factor; VKH, Vogt-Koyanagi-Harada; XIST, X-inactive specific transcript

\section{INTRODUCTION}

Functional regulation of gene expression at the epigenetic, transcriptional and post-transcriptional stage has recently been thoroughly analyzed. It is well established that changes in the long non-coding RNA (lncRNA) and circular RNA (circRNA) levels are associated with the occurrence of multiple disorders, including ocular diseases. Both lncRNAs and circRNAs are relatively newly discovered molecules, but with other non-coding RNA molecules and proteins, they form a network of interactions regulating all cellular processes (Sun \& Kraus, 2015; Tan, 2014; Zhong et al., 2018). Ophthalmological diseases constitute a huge group of various multifactorial disorders, often associated with other systemic diseases. Recently, it was proven that epigenetics and non-coding RNAs must also be taken into account as key players in their development. Here we recapitulate the current data about lncRNAs and circRNAs in ophthalmology and exhibit their potential as molecular markers and therapeutic targets.

\section{CIRCULAR AND LONG NON-CODING RNAS}

lncRNAs are defined as RNA transcripts with little or no coding potential (Sun \& Kraus, 2015). They are longer than 200 nucleotides (nt) and were recently shown to be involved in numerous cellular processes ranging from pluripotency of embryonic stem cells, cellcycle regulation, to the development of cancer, and other diseases. IncRNAs force the formation of ribonucleicprotein complexes, which in turn impact the regulation of gene expression (Rinn \& Chang, 2012). According to the genome location, morphology, sequence, structure, and function features, lncRNAs can be categorized into different groups (Wang et al., 2017a). They can be detected in areas separated from genes encoding known protein-coding transcripts (lincRNAs - long intergenic RNAs) as well as inside protein-coding genes. Genic lncRNAs are situated in exonic or intronic regions and 


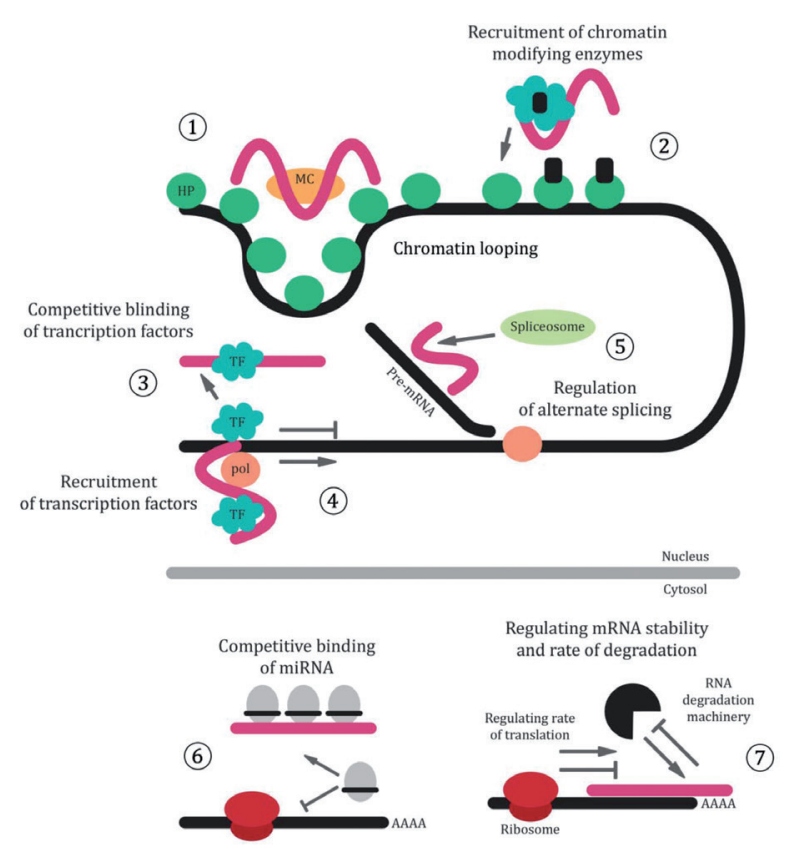

Figure 1. Summary of the IncRNA mechanisms of action.

IncRNAs (fuchsia line) affect gene expression in the nucleus by controlling chromatin looping (1), recruiting chromatin-modifying enzymes to the DNA (2), acting as a decoy to decrease transcription factor availability (3), recruiting transcription factors to the promoter site (4), regulating alternative splicing of the transcript (5). In the cytoplasm, they control miRNA availability by competing with miRNA target sites on the MRNA (6) or by binding to the mRNA to control the rate of translation or RNA degradation (7). Abbreviations: HP - histone proteins; MC - mediator complex; pol - RNA polymerase; TF - transcription factor.

can also be divided into those that overlap proteincoding loci in the sense or antisense direction (Sun \& Kraus, 2015). The biogenesis of lncRNAs, like mRNAs, occurs in the nucleus and depends on RNA Polymerase II and III. IncRNA promotors coincide with epigenetic modifications that regulate transcription factor binding in order to favour or diminish gene expression (Beermann et al., 2016). Post-transcriptional processing of lncRNAs also shares similar modifications with mRNAs including 5'-capping (Ayupe et al., 2015), 3'-polyadenylation, canonical and alternative splicing events and RNA editing processes (Bond \& Fox, 2009; Khandelwal et al., 2015). Interestingly, it was observed that lncRNAs are capable of forming secondary structures based on base-pairing or ribose backbone interactions that determine the final function of the molecule (Beermann et al., 2016; Mercer et al., 2009). High-throughput sequencing of lncRNAs showed that they contain modified bases that also impact their structure and function (Kellner et al., 2010). In addition, post-transcriptional lncRNA modifications are often reversible which confirms that the functional regulation of these molecules is highly complex (Mercer \& Mattick, 2013).

Gene regulation by $\operatorname{lncRNAs}$ occurs at many different levels, through nuclear and cytoplasmic mechanisms. The cellular localization of a lncRNA can indicate its mode of action. Nuclear lncRNAs can be involved in histone modification or direct transcriptional regulation. Cytoplasmic lncRNAs regulate expression at the posttranscriptional level by "sponging" miRNA or interacting with RNA-binding proteins (Long et al., 2017). Figure 1 presents the mechanisms of action of long non-coding RNAs.
lncRNAs were shown to regulate gene expression by their ability to interact with DNA, RNA, and proteins (Tang et al., 2017). Hence, the dysregulation of lncRNA expression patterns can impact cell functions which manifests as a pathological process in disease. Profiling of lncRNAs revealed a difference in their expression between normal and carcinogenic cells (Rasool et al., 2016) and they were recognized as having oncogenic and suppressive roles in neoplasia (Yan \& Wang, 2012). For example, down-regulation of H19, a widely known lncRNA having a role in cancerogenesis, reduces the growth of breast and lung cancers (Chen et al., 2017b; Tessier et al., 2004). In bladder cancer, the upregulation of metastasis-associated lung adenocarcinoma transcript 1 (MALAT1) is associated with the blocking of apoptosis and enhancing cancer cell proliferation and migration (Taheri et al., 2018). lncRNAs are involved in regulating the ageing process, thereby contributing to the development of age-related diseases such as obesity, diabetes, and neurodegeneration. One of the previously mentioned lncRNAs, H19, was reported to control imprinting of various genes, including insulin-like growth factor 2, and to be involved in fat metabolism and deposition (Kim et al., 2016). Many lncRNAs play a role in the regulation of gene expression in the central nervous system. They were described to contribute to synapse formation, maturation of neurons, oligodendrocytes and neuronal-glial fate transition as well as to the regulation of hippocampal development (Mercer et al., 2010). An interesting example of disorders involving lncRNAs is Fragile X syndrome (FXS), a heritable mental disorder caused by expansion of triplet nucleotide repeats in FMR1 gene encoding FMRP - neuronal development protein. It was reported that a vast majority of $\operatorname{lncRNAs}$, which may play a role in FXS, originate from FMR1 gene (Pastori \& Wahlestedt, 2012). There are many other disorders triggered by lncRNA dysregulation, such as rheumatic diseases (Tang et al., 2017), cardiovascular diseases (Sallam et al., 2018) and autoimmune diseases. The regulatory networks in various disorders where gene expression patterns are disturbed often involve lncRNAmiRNA-mRNA interactions and still remain to be precisely characterized in order to better understand the pathomechanisms (Zhang et al., 2017d).

Circular RNAs (circRNA) - the newly described class of single-stranded, non-coding and ubiquitously expressed RNAs, which has been broadly studied in recent years also can serve as useful markers in ocular diseases. circRNAs are commonly classified into three types: exonic circRNAs, exonic-intronic circRNAs, and intronic circRNAs. Most exonic circRNAs occur in the cytoplasm, whereas the other two are mainly found in the nucleus (Memczak et al., 2013). The first circRNA transcripts were identified in the early 1990 s, but a breakthrough in circRNA research occurred in 2013 after the Salzman's group provided evidence that certain human transcripts prefer a circular form rather than linear (Salzman et al., 2012). circRNAs can arise from virtually any part of the genome (exonic and non-coding, transcripts antisense to 5' and 3' UTRs or intergenic regions) which causes significant differences in the length of molecules (Rong et al., 2017). Circular transcripts are considered to be ubiquitous and evolutionary conserved among species, suggesting a significant regulatory role.

Biogenesis of circular transcripts is a highly regulated process. Covalently closed RNA molecules might appear as the result of direct RNA ligation, circularization of introns which escaped from debranching or may derive from the intermediates of processed RNAs. Howev- 
er, the large majority are generated from pre-messenger RNA (pre-mRNA) in the back-splicing process (Wang \& Wang, 2015). Back-splicing is the more advanced type of splicing, however, circRNA that cannot be formed in the canonical manner still requires the presence of canonical spliceosomal machinery and signals (Chen \& Yang, 2015). In contrast to canonical splicing, where an upstream $5^{\prime}$ splice donor site binds to the downstream $3^{\prime}$ splice acceptor site in a sequential order to generate the linear transcripts, back-splicing involves reverse orientation that links a downstream $5^{\prime}$ splice donor site to an upstream 3' splice acceptor resulting in exons in a reversed order (Zhang et al., 2014).

The biogenesis of circRNA also depends on the location of the sequence within the genome. Hence, two general factors promoting the circularization are known - cis-elements and trans-factors-dependent. Circular RNAs classification is based on their origin, taking into account the contribution of cis-elements: exonic, exon-intron (EIciRNAs) and intronic molecules (Jeck et al., 2013). However, Jeck et al. provided evidence (2013) that nearly all circRNAs comprise of exonic sequences of protein-coding genes, formed from one or multiple exons, most frequently 1-5 (Memczak et al., 2013). A variety of RNA-binding proteins - trans-factors also has a significant role in the production of circRNA. Muscleblind (MBL/MBNL1) splicing factor promotes the circularization of certain transcripts. Moreover, AshwalFluss and coworkers in 2014 (Ashwal-Fluss et al., 2014) described the circular form of Muscleblind (circMbl) in flies and humans, resulting from the circularization of the second exon. They discovered putative MBL binding sites present within the intronic regions flanking the second exon. This led to the conclusion that certain MBL isoforms might promote their own exon circularization. Indeed, the level of circMbl was decreased after knockdown of endogenous $M B L$, demonstrating its function as a circMbl promoting factor (Ashwal-Fluss et al., 2014). The following example of binding elements, adenosine deaminases acting on RNA - ADARs, which are known to convert adenosine to inosine in double-stranded RNA, were reported to affect the circRNAs biogenesis in a negative manner. It is suggested that negative regulation is associated with their function - adenosine to inosine (A-to-I) RNA editing. High level of A-to-I editing in double-stranded RNA is known to deplete RNA pairing, which results in diminished pairing and closing of the ends, while lower levels of ADAR promote more stable pairing across the introns and back-splicing for circular RNA production (Chen \& Yang, 2015). The abundance of circRNAs in humans is also regulated by Quaking (QKI) - RNA binding protein, which mediates exon circularization by binding at up- and downstream position of circRNA-forming exons and dimerization coupled with bringing $3^{\prime}$ and $5^{\prime}$ ends of the exon in close proximity which results in joining (Salzman, 2016). Intriguingly, the circularization of linear transcripts is possible after the insertion of Quaking binding sites into the flanking region of linear RNAs (Conn et al., 2015). Even though circular RNA molecules are a relatively new class of long, non-coding RNAs, extensive research has been carried out to determine the function they perform. Many circRNAs are currently considered as regulatory molecules, particularly affecting the function of microRNAs (miRNA), due to the presence of a number of binding sites allowing the interaction to occur. This type of relationship results in circRNA-mediated repression of miRNA function, where endogenous circular transcripts work as miRNA sponges. It was shown that conserved

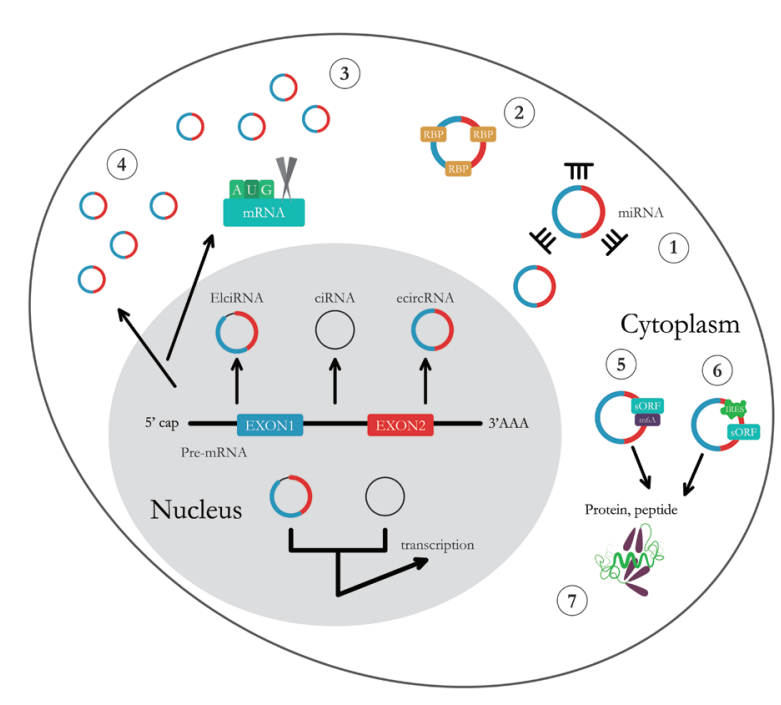

Figure 2. The function of circRNAs in eukaryotic cells.

circRNAs function as microRNA (miRNA) sponges (1). circRNAs bind RNA binding proteins (RBPs) as transcription regulators (2). circRNAs remove start codons from mature mRNAs to reduce protein translation (3) circRNA production competes with canonical pre-mRNA splicing in gene regulation (4). The translation of circRNAs is driven by m6A (5). circRNAs with internal ribosome entry sites (IRESs) can be translated (6). ElciRNAs and ciRNAs promote transcription 7 . Abbreviations: ecircRNA - exonic circRNA; ElciRNA - exonic-intronic circRNA; IRES - internal ribosome entry site; m6A - N6-methyladenosine; RBP - RNA binding protein; sORF - small open reading frame.

miRNA and AGO protein binding sites are enriched in circRNAs. For at least one specific circRNA, ciRS-75 (also called CDR1as), has more than 70 binding sites for miR-7. It was shown in vivo that this circRNA impairs the regulatory role of miR-7. However, whether or not all circRNAs function as miRNA sponges is still not clear. An additional function of circRNAs is the transport of miRNAs. However, available experimental data are not very comprehensive, especially for their global regulation and function (Memczak et al., 2013). Apart from the function as miRNA sponges, circRNAs were shown to regulate alternative splicing and to modulate the expression of parental genes (Guo et al., 2014; Salzman et al., 2013; Salzman et al., 2012; Zhang et al., 2013). Recently, circRNAs were studied in relation to their role in the translation of proteins or peptides (Pamudurti et al., 2017). Four mechanisms of circRNA protein or peptide translation have been identified up to now: (1) involving internal ribosome entry sites (IRESs) within synthetic circRNA; (2) effective circRNAs translation via rolling circle amplification (RCA); (3) translation driven by $\mathrm{N}^{6}{ }_{-}$ methyladenosine (m6A) and (4) a novel cap-independent translation mechanism (Li et al., 2017c; Wang \& Wang, 2015; Yang et al., 2017). More importantly, it is becoming evident that circRNAs may be involved in many types of non-neoplastic diseases, such as e.g. atherosclerotic vascular disease risk, neurological disorders, prion and Alzheimer diseases, rheumatoid arthritis or kidney injury. circRNAs can play a crucial role in tumorigenic processes in different types of cancers, such as: ovarian carcinoma, bladder, papillary thyroid, colorectal, lung or breast cancers (Hu et al., 2018b; Ren et al., 2018; Wang et al., 2018b; Yang et al., 2018a; Zhang et al., 2018). circRNAs were described also as potential disease biomarkers in human saliva and blood and as biomarkers for ageing and gastric cancer (Bachmayr-Heyda et al., 
2015; Guo et al., 2014; Memczak et al., 2015; Zhang et al., 2013). Taken together, these findings indicate that circRNAs have regulating roles in biological development and disease initiation and progression. These properties of circRNA give them the potential to become new clinical diagnostic and prognostic markers and to provide new insight into the treatment of disease. The function of circRNAs in cells is shown in Fig. 2.

\section{CIRCRNAS AND LNCRNAS IN OCULAR DISEASES}

\section{Neovascularization}

Formation of new blood vessels is a process necessary for proper development, but under pathological conditions such as tissue damage or hypoxia abnormal vascular growth occurs. Neovascularization is associated with a number of ocular disorders including corneal injury or infection, retinopathy of prematurity (ROP), age-related macular degeneration (AMD) and proliferative diabetic retinopathy (PDR) (Xu et al., 2014; Zhang et al., 2017c). In all of these conditions the genetic background plays a significant role, however, it does not fully explain the diversity of the clinical picture. Participation of lncRNAs and circRNAs in most biological processes, including cell differentiation, proliferation, and apoptosis, can describe the relationship between gene expression and environmental factors affecting the progress of these diseases (Yan et al., 2014).

\section{Corneal neovascularization}

The causes of corneal neovascularization (CN) include infections, injuries, and graft rejections. The process is strictly controlled by two counterbalancing systems: stimulators and inhibitors of angiogenesis, and can lead to severe vision loss or even blindness (Huang et al., 2015). Huang et al. provided evidence that lncRNAs are potential regulators of $\mathrm{CN}$ pathogenesis. They identified 154 lncRNAs differentially expressed between normal and vascularized corneas of which 60 were down-regulated, and 94 were up-regulated. Expression patterns of randomly selected lncRNAs were also compared to the patterns of antiangiogenic factors - Platelet-Derived Growth Factor (PDGF) and endostatin, and proangiogenic factors - Vascular Endothelial Growth Factor (VEGF) and Nitric Oxide Synthases isoform (iNOS). For example, the human ortholog of NR_033585 was significantly up-regulated in the vascularized corneas and demonstrated similar expression profile as VEGF. By contrast, the human ortholog of lincRNA: chr8:129102060-129109035 reverse strand, was markedly down-regulated and resembled PDGF and endostatin in action (Huang et al., 2015). This study provided a novel insight into $\mathrm{CN}$ pathogenesis and showed that lncRNAs can become potential targets for its prevention or treatment (Li et al., 2016).

Retinopathy of Prematurity

Retinopathy of prematurity (ROP) occurs in premature neonates, in whom at the time of birth the retina remains incompletely vascularized. Instead of proper vascular development, vasculogenesis in the premature neonatal retina is disrupted. At the border of the avascular retina, abnormal vessels grow into the vitreous resulting in haemorrhage and tractional detachment of the retina (Neely \& Gardner, 1998). Development of the retina and its vascularization is a complicated process, and it depends on many factors, which include long non-coding RNAs. Vax2os $I$ is a retina-specific lncRNA that regulates the cell cycle in photoreceptor progenitor cells. Disturbances in its expression pattern result in the delay of the differentiation process (Meola et al., 2012). TUG 1 is another lncRNA found in developing retina. It is responsible for the formation of photoreceptors by activation of specific genes and is also expressed in endothelial cells during ROP (Michalik et al., 2014; Young et al., 2005). Bioinformatics analysis performed by Yang et al. showed several circular and long non-coding RNAs involved in ROP development and progression. They correlated the expression of lncRNAs POLDIP2, GAS5, NEFL and UHRF1 with miRNA-128-3p and miRNA9-5p levels which significantly differ between retinas of neonatal mice and rats with and without ROP. Similarly, circRNA ZNF280C_hsa_circ_001211 and SLAE_ hsa_circ_002083 are also differentially expressed in ROP. Their exact function is still unclear, but the authors implied an association with TGF $\beta$ and PI $3 \mathrm{~K}$-Akt signalling pathways responsible for cell migration and angiogenesis (Yang et al., 2018c). In vitro and in vivo studies of lncRNA metastasis-associated lung adenocarcinoma transcript 1 (MALAT1) revealed that it regulates angiogenesis in developing retina as well as in disorders related to hypoxia. Silencing MALAT 1 expression by siRNA resulted in a reduction of total MALAT 1 levels, both cytoplasmic and nuclear and increased basal endothelial cell migration, whereas cell proliferation was down-regulated. Therefore, inhibition of this lncRNA may become a potential therapeutic strategy for pathological retinal neovascularization (Michalik et al., 2014).

\section{Age-related Macular Degeneration}

Age-related macular degeneration (AMD) is one of the most common causes of adult blindness in developed countries. Clinically, it can be classified into two categories: non-neovascular (also known as "dry" or "nonexudative") or neovascular (also known as "wet" or "exudative") (Yonekawa et al., 2015). Wet AMD is associated with neovascularization originating from the choroidal vasculature and extending into subretinal space (Neely \& Gardner, 1998). The probability of occurrence of AMD is associated with both environmental factors and genetic background.

Caucasian race, female gender, age over 50, Caucasian race, female gender, age over 50 , polymorphism in complement factor $\mathrm{H}$ in the $1 \mathrm{q} 32$ region and variation in the ARMS2 gene on chromosome 10 are well established unmodifiable risk factors. Cigarette smoking is the only proven modifiable factor. However, the influence of other environmental factors such as diet is not excluded (Yonekawa et al., 2015).

AMD is a multifactorial disease that can also be associated with the dysregulation of non-coding RNAs. Vax2os1 and Vax2os2 are lncRNAs that can interact with nuclear factor $x \mathrm{~B}(\mathrm{NF}-x \mathrm{~B})$. NF- $x \mathrm{~B}$ is a transcription factor involved in the regulation of the expression of more than 100 genes. It plays an essential role in cell migration, invasion and inflammation reaction during angiogenesis (Kaarniranta \& Salminen, 2009). In the murine model of choroidal neovascularization (CNV) as well as in aqueous humour of CNV patients $\operatorname{Vax} 20 s 1$ and $\operatorname{Vax} 20 s 2$ are significantly down-regulated. They are antisense transcripts of $V a x 2$ gene, a critical regulator of eye development, and are highly expressed in the choroid and retinal vasculature. They can be potentially used as biomarkers of early CNV (Li et al., 2016; Xu et al., 2014). 
Dry AMD progression is slower than wet AMD and less likely leads to loss of the central visual field. It also causes severe visual impairment, especially in the advanced form of the disease called geographic atrophy which can develop in areas of regressed large drusen but also independently, in areas of prior pigmentary changes suggesting RPE dysfunction (Yonekawa et al., 2015). Early AMD was reported to be influenced by oxidative stress, abnormal lipid metabolism, cell apoptosis and dysfunction of the immune system, whereas lncRNAs are also associated with these processes (Sun \& Kraus, 2015). Zhu et al. found 64 lncRNAs dysregulated in early AMD and established that they could play an important role in AMD development. Mapping of lncRNA-related dysregulated mRNAs showed that most of them locate in phototransduction and purine metabolism pathways. They evaluated the expression level of one lncRNA - RP11-23406.2 in vitro and studied its activity in the ageing model of cultured retinal pigmented epithelium (ARPE-19) cells. RP-1123406.2 was downregulated in early AMD, and its exogenous application improved cell viability and reduced the rate of early apoptosis (Zhu et al., 2017). ZNF503-AS1 is an intergenic lncRNA up-regulated during RPE differentiation and down-regulated in RPE-choroid of atrophic AMD. It can potentially promote RPE differentiation through inhibiting its target ZNF503. ZNF503-AS1 is regulated by NF-xB which is involved in cellular processes such as inflammation and differentiation of RPE. Targeting both RP-1123406.2 and ZNF503-AS1 is a potential therapeutic strategy for atrophic AMD (Chen et al., 2017a).

\section{Diabetic retinopathy}

Diabetic retinopathy (DR) is one of the most common vascular complications in patients with long-term diabetes. Changes in microvascular circulation in the retina under hyperglycemia conditions include increased proliferation and permeability of endothelial cells, abnormal neovascularization, and edema. Elevated blood glucose level results in oxidative stress, inflammation, neuronal dysfunction, apoptosis of the retinal ganglion cells and activation of glial cells. In all of these processes, lncRNAs play a significant role by interacting with chemokine and mitogen-activated protein kinase (MAPK) signalling pathways (Gong \& Su, 2017; Pradhan et al., 2016).

Myocardial infarction associated transcript (MIAT) is a retinal ncRNA 2 (RNCR2) that is highly expressed in retinal precursor cells and the retinas of diabetic rats. Its expression is also observed in Müller cells isolated from diabetic mice. Apoptotic activity is associated with the interaction with NF- $x \mathrm{~B}$ (heterodimer that comprises p 65 and p50) which selectively binds to the MLAT promoter. $M L A T$ silencing under diabetic conditions inhibits apoptosis and improves visual functions (Gong \& Su, 2017; Zhang et al., 2017a).

Another lncRNA involved in the regulation of epithelial cell function is $M A L A T 1$. Its cooperation with p38 MAPK signalling pathway affects cell proliferation, migration, and tube formation. Knockdown of MALAT1 in cell lines induces a change of phenotype from proliferative to migratory, and in vivo silencing reduces vascular growth (Michalik et al., 2014). Diabetic retinopathy progression is influenced by a complex crosstalk between angiogenesis and inflammation. MALAT1 also participates in inflammatory activation. Under hyperglycemic conditions, it is upregulated in human retinal endothelial cells (HRECs). Its siRNA silencing reduces the expression of several inflammatory cytokines, including tumour necrosis factor-alpha (TNF $\alpha$ ), interleukin-6 (IL-6), interleukin-1 $\beta$ (IL-1 $\beta$ ) and monocyte chemotactic protein-1 (MCP-1). Also, the histone methyltransferase component of polycomb repressive complex 2 (PRC2) was downregulated in HERCs treated with siMALAT1, demonstrating its ability to influence the expression on the protein level. Reduction of TNF $\alpha$, IL- 6 , IL- $1 \beta$ and MCP1 levels in $M A L A T 1$ knockdown mice with induced diabetes confirmed the importance of $M A L A T 1$ genes in the regulation of inflammation (Biswas et al., 2018). MALAT1 also promotes the inflammatory reaction in microglial cells by 'sponging' miR-124. Overexpression of MALAT1 in Amadori-glycated albumin (AGA) treated microglial cells results in downregulation of miR-124 which in turn leads to MCP-1 upregulation (Dong et al., 2018).

$M E G 3$ can be responsible for enhanced retinal vessel dysfunction, capillary degeneration, increased epithelial permeability, and inflammation. It is significantly downregulated in diabetic mice retinas and re-establishing its expression may serve as a therapeutic strategy in diabetes-related vascular complications (Qiu et al., 2016).

SOX2 overlapping transcript (SOX2OT) and retinal ncRNA3 (RNCR3) are lncRNAs also dysregulated under hyperglycemic conditions. SOX2OT is involved in pathways of apoptosis and cell viability connected with transcription factor NRF2 and its target - HO-1 gene. It is downregulated in retinal ganglion cell lines exposed to high glucose levels and oxidative stress and in the retina of diabetic mice (Li et al., 2017a). RNCR3 participates in the retinal development and neuronal and oligodendrocyte differentiation. It is also up-regulated in $\mathrm{RF} / 6 \mathrm{~A}$ cell line and the retina of diabetic mice, similarly to some interleukins and inflammatory factors like VEGF and TNF $\alpha$ (Liu et al., 2016; Rapicavoli et al., 2010).

Interaction of circular RNAs with miRNAs involved in proliferative and apoptotic pathways may also affect the retinal vascular dysfunction. Zhang et al. identified 529 circRNAs differentially expressed between diabetic and non-diabetic retinas. They thoroughly analyzed circ_0005015 expression profile and confirmed it is up-regulated in the plasma, vitreous samples and fibrovascular membranes of diabetic patients. circ_0005015 regulates retinal endothelial cell proliferation, migration, and tube formation. MMP-2, XIAP, and STAT3 are proteins involved in regulation of cell cycle, proliferation, and apoptosis. circ_0005015 acts as a sponge for miR$519 d-3 p$ inhibiting its activity and interfering with MMP2, XIAP, and STAT3 expression (Zhang et al., 2017b).

The circHIPK 3 expression is also up-regulated in retinal endothelial cells exposed to high glucose concentration. It acts as an endogenous $m i \mathrm{R}-30 a-3 p$ sponge. Similarly to circ_0005015/miR-519d-3p, it effectively up-regulates vascular endothelial growth factors expression and intensifies endothelial proliferation, vascular leakage, and inflammation (Shan et al., 2017).

\section{Proliferative vitreoretinopathy}

Proliferative vitreoretinopathy (PVR) is a serious complication of retinal detachment and vitreoretinal surgery. It can lead to severe vision reduction due to retinal redetachment caused by the formation of preretinal and epiretinal membrane (ERM) tractions. Several cell types are associated with the PVR pathogenesis, including retinal pigment epithelial (RPE) cells, fibroblasts, glial cells, and inflammatory cells. RPE cells are the largest cellular component in epiretinal membranes, and, importantly, they undergo dedifferentiation process - epithelial-mesenchymal transition (EMT) - in which they acquire 
a mesenchymal phenotype (Kaneko \& Terasaki, 2017; Yang et al., 2016). This process is the main contributor to PVR progression and involves a number of molecular pathways affecting cell proliferation and migration. Zhou et al. established that 78 lncRNAs were abnormally expressed in ERMs of PVR patients. They focused on $M A L A T 1$ whose up-regulation contributed to RPE cell proliferation, migration, and epithelial-mesenchymal transition. It was also found that its level in peripheral blood samples of the patients differs before and after PVR surgical treatment. This evidence suggests $M A L A T 1$ could be used for the diagnosis and monitoring of PVR progression (Wan et al., 2017; Zhou et al., 2015).

Yang and coworkers (Yang et al., 2016) confirmed the role of MALAT1 in PVR pathogenesis. They reported it is involved in EMT upon transforming growth factor $\beta 1$ (TGFß1) induction. Knock-down of $M A L A T 1$ by specific siRNA resulted in TGF $\beta 1$-induced morphological change inversion, suppression of migration and proliferation of RPE cells.

\section{Glaucoma}

Glaucoma is the leading cause of irreversible vision loss. It is a group of eye diseases characterized by retinal neurodegeneration comprising retinal ganglion cell loss, optic disc excavation that results in progressive loss of visual field (Abu-Amero et al., 2015). The most common type of glaucoma is primary open angle glaucoma (POAG) in which the anterior iridocorneal chamber angle is opened. The condition is often associated with increased intraocular pressure (IOP), but can also occur with normal IOP - normal tension glaucoma (NTG). Glaucoma is a multifactorial disorder with genetic and epigenetic components (Abu-Amero et al., 2015; Gauthier \& Liu, 2017).

The cyclin-dependent kinase inhibitor $2 \mathrm{~B}$ antisense non-coding RNA (CDKN2B-AS1) also known as $A N$ RIL is a lncRNA transcribed in an antisense direction, located on chromosome 9p21. Several studies showed that ANRIL is associated with POAG, but its effects are not thoroughly understood. The genotype/phenotype analysis revealed a significant correlation between $C D$ KN2B-AS1 and decreased intraocular pressure in POAG patients. It suggests that $A N R I L$ modifies the vulnerability of the optic nerve and modulates neurodegeneration. Patients carrying the risk alleles in ANRIL region are predisposed to develop POAG at lower IOP levels and to exhibit normal tension glaucoma (Nakano et al., 2012; Shiga et al., 2017).

Wang et al. investigated $c Z R A N B 1$ - a circRNA significantly upregulated in glaucoma-induced retinal neurodegeneration. It is mainly expressed in the cytoplasm of glial cells, implying a regulatory activity at the post-transcriptional level. It also may suppress the expression of miR-217 resulting in increased Müller cells proliferation. cZRANB1 knock-down decreases retinal reactive gliosis and reduces glaucoma-induced retinal ganglion cell apoptosis. Additionally, they established that overexpression of transcription factor RUNX2 reverses $C Z R A N B 1$ knockdown effects. The cZRANB1/miR-217/RUNX2 signalling network is a potential therapeutic target for treating retinal neurodegeneration (Wang et al., 2018a).

Extensive proliferation of glaucoma Tenon's capsule fibroblasts (GTF) and subsequent scaring is the main cause of glaucoma filtration surgery (GFS) failure. Transforming growth factor $\beta 2$ (TGF $\beta 2$ ) is upregulated after GFS surgery. It regulates proliferative ability, apoptosis, and differentiation of fibroblasts. TGF 32 acts via different molecular pathways, including interacting with nuclear factor 2 (Nrf2), which is involved in retinal ganglion cells apoptosis and fibroblasts proliferation. Wang et al. investigated the role of $M E G 3$ lncRNA in the TGF 32 -stimulated proliferation of fibroblasts. The overexpression of $M E G 3$ was correlated with Nrf2 upregulation. Their possible direct interaction causes a synergistic effect of reduced GTF proliferation, suggesting that MEG3 may act as a therapeutic tool for improving glaucoma filtration surgeries (Wang et al., 2017b).

TGF $\beta$ is also involved in lncRNA Growth Arrest Specific 5 (GAS5) pathway. Retinal ganglion cells (RGC) transfected with siRNA targeting GAS5 showed increased proliferation and differentiation. The axon length was significantly improved in GAS5-low-expression group compared to the control group. These results revealed that high expression of lncRNA GAS5 may promote glaucoma progression and ganglion cell degeneration. RGCs treated with exogenously administrated TGF $\beta$ demonstrated decreased GAS5 levels in a timeand dose-dependent manner, indicating its protective potential in glaucoma neurodegeneration (Xu \& Xing, 2018).

\section{OTHER OPHTHALMOLOGIC DISORDERS}

\section{Ocular malignancy}

The expression of lncRNAs in cancerogenesis is well established. Du and coworkers (Du et al., 2013) performed a global analysis of more than 10000 lncRNA genes in 1300 tumour samples of different cancer types. They determined lncRNAs are associated with cellular oncogenic potential and promote metastasis but may also act as tumour suppressors (Du et al., 2013; Sun \& Kraus, 2015).

There are several lncRNAs related to uveal melanoma. CRNDE is a lncRNA that promotes cell proliferation and invasion through the mTOR signalling pathway and modulates the methylation status of histones. Mutation SF3B1 related to the alternative splicing of CRNDE genes is associated with good prognosis in patients with uveal melanoma (Furney et al., 2013). Another lncRNA LINC-ROR is up-regulated in ocular melanoma cell lines and tumour specimens. By repelling the histone methyltransferase EHMT2 (also known as G9a), it activates the TESC promoter and causes an oncogenic effect (Fan et al., 2015; Wan et al., 2017).

Robertson and coworkers (Robertson et al., 2017) provided a comprehensive multiplatform analysis of 80 uveal melanomas. They identified four molecularly distinct tumour subtypes, two associated with poor prognosis (monosomy of chromosome 3 - M3) and two with better prognosis (disomy of chromosome 3 - D3). Investigating the expression profile of 8,167 lncRNAs, they noted that well-established cancer-associated LINC00152 (CYTOR) and BANCR are overexpressed in poor-prognosis subgroups. The upregulation of LINC00152 and $B A N C R$ correlates with invasion, cell migration and proliferation (Robertson et al., 2017). Also, IncRNA PVT1, localized in well-known cancer risk region $8 \mathrm{q} 24$, was among the most differentially expressed transcripts in poor-prognosis groups. Its oncogenic potential is associated with MYC transcription factors. PVT1 controls MYC expression at the post-transcriptional level by increasing the protein's stability and promotes cell proliferation (Colombo et al., 2015). The quantity of PVT1, 
Table 1. Long non-coding RNAs and circular RNAs in ophthalmologic disorders.

\begin{tabular}{|c|c|c|c|c|}
\hline Ocular disease & IncRNA & Dysregulation & Function & References \\
\hline \multirow{2}{*}{$\begin{array}{l}\text { Corneal Neovascularisa- } \\
\text { tion }\end{array}$} & NR_033585 & Up-regulated & Stimulates angiogenesis & Huang et al., 2015 \\
\hline & $\begin{array}{l}\text { chr8:129102060- } \\
129109035\end{array}$ & Down-regulated & Stimulates angiogenesis & Huang et al., 2015 \\
\hline \multirow{4}{*}{$\begin{array}{l}\text { Retinopathy of Prema- } \\
\text { turity }\end{array}$} & Vax2os1 & & $\begin{array}{l}\text { Regulates cell cycle in photoreceptor } \\
\text { progenitor cells }\end{array}$ & Meola et al., 2012 \\
\hline & TUG1 & & Formation of photoreceptors & Young et al., 2005 \\
\hline & $\mathrm{RNCR} 2 / \mathrm{MIAT}$ & & Retinal cell fate specification & $\begin{array}{l}\text { Rapicavoli et al., } \\
2010\end{array}$ \\
\hline & MALAT1 & & $\begin{array}{l}\text { Regulates angiogenesis in developing } \\
\text { retina }\end{array}$ & $\begin{array}{l}\text { Michalik et al., } \\
2014\end{array}$ \\
\hline $\begin{array}{l}\text { Wet Age-related Macular } \\
\text { Degeneration }\end{array}$ & $\begin{array}{l}\text { Vax2os1 } \\
\text { Vax2os2 }\end{array}$ & Down-regulated & $\begin{array}{l}\text { Regulate eye development by interac- } \\
\text { ting with NF- KB }\end{array}$ & $\begin{array}{l}\text { Kaarniranta \& } \\
\text { Salminen, } 2009\end{array}$ \\
\hline $\begin{array}{l}\text { Dry Age-related Macular } \\
\text { Degeneration }\end{array}$ & RP11-23406.2 & Down-regulated & $\begin{array}{l}\text { Associated with apoptosis and cell } \\
\text { viability pathways }\end{array}$ & Zhu et al., 2017 \\
\hline \multirow{7}{*}{ Diabetic Retinopathy } & RNCR2/MIAT & Up-regulated & $\begin{array}{l}\text { Promotes epithelial cell proliferation, } \\
\text { migration, and tube formation, } \\
\text { interacts with NF- } \mathrm{KB}\end{array}$ & $\begin{array}{l}\text { Rapicavoli et al., } \\
2010\end{array}$ \\
\hline & MALAT1 & & $\begin{array}{l}\text { Affects cell proliferation, migration, } \\
\text { and tube formation, } \\
\text { interacts with p38 MAPK }\end{array}$ & $\begin{array}{l}\text { Michalik et al., } \\
2014\end{array}$ \\
\hline & MEG3 & Down-regulated & Enhances retinal vessel dysfunction & Qiu et al., 2016 \\
\hline & SOX2OT & Down-regulated & $\begin{array}{l}\text { Promotes neurodegeneration, apop- } \\
\text { tosis, affects cell viability }\end{array}$ & Li et al., 2017a \\
\hline & RNCR3 & Up-regulated & $\begin{array}{l}\text { Increases cell viability, proliferation, } \\
\text { and migration }\end{array}$ & Liu et al., 2016 \\
\hline & circ_0005015 & Up-regulated & $\begin{array}{l}\text { Acts as a miR- } 519 d-3 p \text { sponge, } \\
\text { regulates endothelial cell prolifera- } \\
\text { tion, migration and tube formation }\end{array}$ & $\begin{array}{l}\text { Zhang et al., } \\
2017 \mathrm{~b}\end{array}$ \\
\hline & circHIPK3 & Up-regulated & $\begin{array}{l}\text { Acts as } m i R-30 a-3 p \text { sponge, } \\
\text { intensifies endothelial proliferation, } \\
\text { vascular leakage, and inflammation }\end{array}$ & Shan et al., 2017 \\
\hline $\begin{array}{l}\text { Proliferative Vitreoretin- } \\
\text { opathy }\end{array}$ & MALAT1 & Up-regulated & $\begin{array}{l}\text { Promotes epithelial-mesenchymal } \\
\text { transition }\end{array}$ & Yang et al., 2016 \\
\hline \multirow{2}{*}{$\begin{array}{l}\text { Primary Open Angle Glau- } \\
\text { coma }\end{array}$} & $\begin{array}{l}\text { CDKN2B-AS1/ } \\
\text { ANRIL }\end{array}$ & & $\begin{array}{l}\text { Modifies the vulnerability of the optic } \\
\text { nerve and modulates neurodegenera- } \\
\text { tion }\end{array}$ & $\begin{array}{l}\text { Nakano et al., } \\
\text { 2012; Shiga et al., } \\
2017\end{array}$ \\
\hline & cZRANB1 & Up-regulated & $\begin{array}{l}\text { Suppresses the expression of miR-217, } \\
\text { increases Müller cell proliferation }\end{array}$ & Wang et al., 2018a \\
\hline \multirow{3}{*}{ Uveal melanoma } & CRNDE & Up-regulated & $\begin{array}{l}\text { Promotes cell proliferation and inva- } \\
\text { sion }\end{array}$ & Furney et al., 2013 \\
\hline & LINC-ROR & Up-regulated & Induces pro-oncogenic effect & Fan et al., 2015 \\
\hline & LINC00152 & Up-regulated & $\begin{array}{l}\text { Induces proliferation, cell invasion, } \\
\text { and migration }\end{array}$ & $\begin{array}{l}\text { Robertson et al., } \\
2017\end{array}$ \\
\hline
\end{tabular}




\begin{tabular}{|c|c|c|c|c|}
\hline & BANCR & Up-regulated & $\begin{array}{l}\text { Induces proliferation, cell invasion } \\
\text { and migration }\end{array}$ & $\begin{array}{l}\text { Robertson et al., } \\
2017\end{array}$ \\
\hline & PVT1 & Up-regulated & $\begin{array}{l}\text { Stabilization of MYC protein, coopera- } \\
\text { tion with MYC protein }\end{array}$ & $\begin{array}{l}\text { Colombo et al., } \\
2015\end{array}$ \\
\hline \multirow{10}{*}{ Retinoblastoma } & MEG3 & Down-regulated & Early stages marker & Gao \& Lu, 2016 \\
\hline & BANCR & Up-regulated & $\begin{array}{l}\text { Promotes choroidal invasion and op- } \\
\text { tic nerve invasion }\end{array}$ & Su et al., 2015 \\
\hline & AFAP1-AS1 & Up-regulated & $\begin{array}{l}\text { Induces proliferation, cell migration } \\
\text { and invasion }\end{array}$ & Hao et al., 2018 \\
\hline & HOTAIR & Up-regulated & $\begin{array}{l}\text { Induces proliferation, cell migration } \\
\text { and invasion } \\
\text { Targets miR-613 }\end{array}$ & Yang et al., 2018b \\
\hline & $\mathrm{H} 19$ & Up-regulated & $\begin{array}{l}\text { Promotes proliferation, cell migration } \\
\text { and invasion }\end{array}$ & Li et al., 2018a \\
\hline & PANDAR & Up-regulated & $\begin{array}{l}\text { Induces proliferation, cell migration } \\
\text { and invasion }\end{array}$ & Sheng et al., 2018 \\
\hline & PlncRNA1 & Up-regulated & $\begin{array}{l}\text { Promotes proliferation, cell migration } \\
\text { and invasion }\end{array}$ & Wang et al., 2018c \\
\hline & LINC00152 & Up-regulated & $\begin{array}{l}\text { Promotes proliferation, cell migration } \\
\text { and invasion }\end{array}$ & Li et al., 2018b \\
\hline & THOR & Up-regulated & $\begin{array}{l}\text { Induces proliferation, cell migration } \\
\text { and invasion }\end{array}$ & Shang, 2018 \\
\hline & XIST & Up-regulated & $\begin{array}{l}\text { Induces proliferation, cell migration } \\
\text { and invasion } \\
\text { Targets miR-124 }\end{array}$ & Hu et al., 2018a \\
\hline Uveitis & Rs6871626 & & Up-regulating IL10 expression & Yue et al., 2018 \\
\hline \multirow{2}{*}{ Strabismus } & IncMyoD & & Regulation of muscles differentiation & Ma et al., 2018 \\
\hline & Inc133b & & Regulation of muscles differentiation & Ma et al., 2018 \\
\hline \multirow{3}{*}{ Cataract } & MIAT & Up-regulated & $\begin{array}{l}\text { Stimulates proliferation and migration } \\
\text { of lens epithelial cells }\end{array}$ & Shen et al., 2016 \\
\hline & TUG1 & Up-regulated & $\begin{array}{l}\text { Suppresses miR-421, induction of } \\
\text { apoptosis }\end{array}$ & Li et al., 2017b \\
\hline & KCNQ10T1 & Up-regulated & $\begin{array}{l}\text { Stimulates proliferation and epithe- } \\
\text { lial-mesenchymal-transition }\end{array}$ & Chen et al., 2018 \\
\hline
\end{tabular}

as well as LINC00152, was significantly dependent on DNA methylation.

CYSLTR2 may act as a better prognostic marker of uveal melanoma as its expression was markedly lower in the D3 molecular subtype of the tumour (Robertson et al., 2017).

Retinoblastoma is an embryonic malignant tumour that arises from foetal stem cells in the nuclear layer of the retina. It is the most frequent primary intraocular malignancy in children. MEG3 is a potential therapeutic target and disease-specific marker for early diagnosis of this tumour. It is down-regulated in retinoblastoma samples, and its levels are associated with the stages of cancer. The MEG3 level in early-stage patients was significantly higher than in advanced-stage patients and correlated with nodal or distant metastasis. Its down-regulation correlates with progression and poor prognosis in retinoblastoma and is an independent marker for predicting the clinical outcome of retinoblastoma patients (Gao \& Lu, 2016).

AFAP1-AS1 (actin filament-associated protein 1 antisense RNA 1) overexpression is strongly correlated with tumour size, optic nerve invasion, and choroidal invasion. Knockdown of AFAP1-AS1 decreased cell proliferation, migration, and invasion and blocked cell cycle progression (Hao et al., 2018). Similarly, HOTAIR (HOX antisense intergenic RNA) high expression was noticed in retinoblastoma tumours bigger than $10 \mathrm{~mm}$, bilateral and with lymph nodal metastasis. Contrarily, miR-613 was significantly down-regulated in the same samples. 
HOTAIR targets miR-613 and promotes endothelial-mesenchymal transition (EMT) in retinoblastoma cells and its silencing with siRNA resulted in miR-613 upregulation and induced apoptosis (Yang et al., 2018b).

$H 19$ and $P A N D A R$ (promoter of CDKN1A antisense DNA damage-activated RNA) are also overexpressed in $\mathrm{RB}$ cells. They affect cell proliferation, invasion, and migration through vimentin, CDK1, p53 and E-cadherin regulation (Li et al., 2018a; Sheng et al., 2018).

PlncRNA-1 (prostate cancer-up-regulated long noncoding RNA 1) modulates carbonyl reductase 3 (CBR3) activity, and LINC00152 (long noncoding RNA00152) inactivates $\mathrm{Ki}-67, \mathrm{Bcl}-2$, and MMP-9 at the post-transcriptional level. In both cases increased proliferation, invasion and migration were observed (Li et al., 2018b; Wang et al., 2018c).

XIST (X-inactive specific transcript) oncogenic activity is associated with its ability to 'sponge' miR-124 and thereby to up-regulate the signal transducer and activator of transcription 3 (STAT3). Its knock-down resulted in significant inhibition of cell proliferation, cell cycle arrest at the G1/G0 phase and the promotion of apoptosis, probably through negative regulation of miR-124/STAT3 axis (Hu et al., 2018a).

Overexpression of THOR (testis-associated highly conserved oncogenic lncRNA) significantly enhances the malignant phenotype transformation of retinoblastoma cells. The process is mediated through up-regulation of c-Myc expression via enhancing its interaction with TGF2BP1 protein (Shang, 2018).

$B A N C R$ is also an oncogenic lncRNA, and its overexpression in both retinoblastoma tissues and cell lines is associated with tumour size, choroidal invasion, and optic nerve invasion. Silencing $B A N C R$ results in suppression of proliferation, migration, and cell invasion. Its overexpression is correlated with an unfavourable prognosis and, similarly to lncRNAs mentioned above, it can be used as an independent prognostic biomarker for retinoblastoma patients. It is also a promising therapeutic target (Su et al., 2015).

\section{Uveitis}

The genetic background of autoimmune diseases is established. Almost $50 \%$ of anterior uveitis patients carry the human leucocyte antigen B27 (HLA-B27). Vogt-Koyanagi-Harada (VKH) disease and Behcet's disease (BD) are both autoimmune syndromes that include uveitis. They are also both associated with several genes, for example, IL17F, IL23A, TNFAIP3, and HLA-DR4, HLA-DRw53 (VKH) and HLA-B51 (BD). Although many genes are connected with autoimmune uveitis, its exact aetiology is still unclear. Yue et al. revealed that some lncRNAs also are involved in the inflammatory response in VKH and BD patients. Rs6871626 was shown to increase anti-inflammatory cytokine IL-10 production by regulating the LOC285627 gene expression (Yue et al., 2018). Because lncRNAs are relatively recently discovered molecules, their exact role in autoimmune uveitis is yet to be determined.

\section{Strabismus}

Strabismus is a common ocular disorder that is caused by the impairment of central neural pathways and maladjusted extraocular muscles (EOMs). EOMs control eye position and play a crucial role in the development of this ailment. Ultrastructural examination of EOMs samples revealed myofilament disintegration, sarcomere destruction, collagen biosynthesis and fibrosis. There are also few lncRNAs regulating muscles differentiation, for

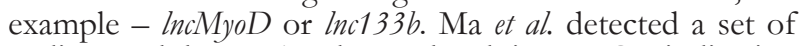
coding and lncRNAs dysregulated in EMOs indicating that they are also involved in the pathogenesis of strabismus, but their participation is not yet fully defined (Ma et al., 2018).

\section{Cataract}

Age-related cataract is one of the most common chronic disorders of ageing. Posterior capsule opacification (PCO) is a frequent complication of the cataract surgery. Many morphological and functional changes take place during cataract pathogenesis, including increased proteolysis, altered cell cycle, DNA damage and the change in growth and differentiation of lens epithelial cells (LECs). Shen et al. examined the role of lncRNAs in cataract development. They identified 38 differentially expressed lncRNAs in cataractous lenses, among which MIAT was the most abundant. It was overexpressed in pathological tissue, plasma fraction of the whole blood and aqueous humour of the cataract patients. MIAT was also involved in posterior capsule opacification process, and its knock-down inhibited TNF- $\alpha$-induced proliferation and migration of LECs. This study provided a novel insight into the pathogenesis of age-related cataract and suggests that $M L A T$ can act as a cataract-specific biomarker and that its silencing can affect PCO formation (Shen et al., 2016; Wan et al., 2017).

Recently a few more lncRNAs were identified to be associated with cataract occurrence. $\mathrm{Li}$ et al. observed that TUG1 and caspase-3 were overexpressed and the miR-421 expression was reduced in cataract lenses compared to healthy tissue. TUG1 negatively regulated miR421 expression and promoted UV irradiation-induced SAR01/04 cells apoptosis (Li et al., 2017b).

Similarly to TUG1, KCNQ1OT1 is also overexpressed in human cataract lens anterior capsular samples and SRA01/04 cell line treated with $\mathrm{H}_{2} \mathrm{O}_{2}$. Down-regulation of KCNQ1OT1 inhibited SRA01/04 cell proliferation and epithelial-mesenchymal-transition (EMT), which are the key phases in cataract formation. This effect was related to the impact of KCNQ1OT1 on SMAD4, a critical intracellular mediator of proliferation and EMT.

Crystallin gene mutations, especially $\beta \mathrm{B} 2$ crystallin (CRYBB2), are associated with cataract formation. Jia et al. identified 149 up-regulated, and 180 down-regulated lncRNAs in CRYBB2 knock-out induced cataract mice model versus healthy mice. The paper highlighted the need for further research on dysregulated lncRNAs (Jia et al., 2018).

In conclusion, the formation of the cataract is an extremely complex issue associated with several mechanisms and complex networks in which lncRNAs play an important role (Chen et al., 2018).

\section{CONCLUSIONS}

The complexity of cellular processes still leaves much to be discovered. However, a better understanding of epigenetic relationships in cellular pathways gives us the possibility to develop effective and specific biomarkers and novel therapeutic strategies in various ophthalmologic diseases. As summarized in Table 1, there are several dysregulated lncRNAs and circRNAs in ophthalmologic disorders, but their exact participation in the development of these types of diseases is still poorly understood, and more research is required. 


\section{Acknowledgements}

We thank Dr. Patrick McDevitt Perrigue for critical reading of the manuscript and language editing.

\section{REFERENCES}

Abu-Amero K, Kondkar AA, Chalam KV (2015) An Updated Review on the Genetics of Primary Open Angle Glaucoma. Int J Mol Sci 16: 28886-28911. http://doi.org/10.3390/ijms161226135

Ashwal-Fluss R, Meyer M, Pamudurti NR, Ivanov A, Bartok O, Hanan M, Evantal N, Memczak S, Rajewsky N, Kadener S (2014) circRNA biogenesis competes with pre-mRNA splicing. Mol Cell 56: 55-66. http://doi.org/10.1016/j.molcel.2014.08.019

Ayupe AC, Tahira AC, Camargo L, Beckedorff FC, Verjovski-Almeida S, Reis EM (2015) Global analysis of biogenesis, stability and subcellular localization of lncRNAs mapping to intragenic regions of the human genome. RNA Biol 12: 877-892. http://doi.org/10.1080 /15476286.2015.1062960

Bachmayr-Heyda A, Reiner AT, Auer K, Sukhbaatar N, Aust S, Bachleitner-Hofmann T, Mesteri I, Grunt TW, Zeillinger R, Pils D (2015) Correlation of circular RNA abundance with proliferation-exemplified with colorectal and ovarian cancer, idiopathic lung fibrosis, and normal human tissues. Sci Rep 5: 8057. http://doi. org/10.1038/srep08057

Beermann J, Piccoli MT, Viereck J, Thum T (2016) Non-coding RNAs in Development and Disease: Background, Mechanisms, and Therapeutic Approaches. Physiol Rev 96: 1297-1325. http://doi. org/10.1152/physrev.00041.2015

Biswas S, Thomas AA, Chen S, Aref-Eshghi E, Feng B, Gonder J, Sadikovic B, Chakrabarti S (2018) MALAT1: An Epigenetic Regulator of Inflammation in Diabetic Retinopathy. Sci Rep 8: 6526. http://doi.org/10.1038/s41598-018-24907-w

Bond CS, Fox AH (2009) Paraspeckles: nuclear bodies built on long noncoding RNA. J Cell Biol 186: 637-644. http://doi.org/10.1083/ jcb.200906113

Chen B, Ma J, Li C, Wang Y (2018) Long noncoding RNA KCNQ1OT1 promotes proliferation and epithelialmesenchymal transition by regulation of SMAD4 expression in lens epithelial cells. Mol Med Rep. http://doi.org/10.3892/mmr.2018.8987

Chen LL, Yang L (2015) Regulation of circRNA biogenesis. RNA Biol 12: 381-388. http://doi.org/10.1080/15476286.2015.1020271

Chen X, Jiang C, Qin B, Liu G, Ji J, Sun X, Xu M, Ding S, Zhu M, Huang G, Yan B, Zhao C (2017a) LncRNA ZNF503-AS1 promotes RPE differentiation by downregulating ZNF503 expression. Cell Death Dis 8: e3046. http://doi.org/10.1038/cddis.2017.382

Chen X, Yan CC, Zhang X, You ZH (2017b) Long non-coding RNAs and complex diseases: from experimental results to computational models. Brief Bioinform 18: 558-576. http://doi.org/10.1093/bib/ bbw060

Colombo T, Farina L, Macino G, Paci P (2015) PVT1: a rising star among oncogenic long noncoding RNAs. Biomed Res Int 2015: 304208. http://doi.org/10.1155/2015/304208

Conn SJ, Pillman KA, Toubia J, Conn VM, Salmanidis M, Phillips CA, Roslan S, Schreiber AW, Gregory PA, Goodall GJ (2015) The RNA binding protein quaking regulates formation of circRNAs. Cell 160: 1125-1134. http://doi.org/10.1016/j.cell.2015.02.014

Dong N, Xu B, Shi H (2018) Long noncoding RNA MALAT1 acts as a competing endogenous RNA to regulate Amadori-glycated albumin-induced MCP-1 expression in retinal microglia by a microRNA124-dependent mechanism. Inflamm Res. http://doi.org/10.1007/ s00011-018-1184-1

Du Z, Fei T, Verhaak RG, Su Z, Zhang Y, Brown M, Chen Y, Liu XS (2013) Integrative genomic analyses reveal clinically relevant long noncoding RNAs in human cancer. Nat Struct Mol Biol 20: 908-913. http://doi.org/10.1038/nsmb.2591

Fan J, Xing Y, Wen X, Jia R, Ni H, He J, Ding X, Pan H, Qian G, Ge S, Hoffman AR, Zhang H, Fan X (2015) Long non-coding RNA ROR decoys gene-specific histone methylation to promote tumorigenesis. Genome Biol 16: 139. http://doi.org/10.1186/s13059-0150705-2

Furney SJ, Pedersen M, Gentien D, Dumont AG, Rapinat A, Desjardins L, Turajlic S, Piperno-Neumann S, de la Grange P, RomanRoman S, Stern MH, Marais R (2013) SF3B1 mutations are associated with alternative splicing in uveal melanoma. Cancer Discov 3: 1122-1129. http://doi.org/10.1158/2159-8290.CD-13-0330

Gao Y, Lu X (2016) Decreased expression of MEG3 contributes to retinoblastoma progression and affects retinoblastoma cell growth by regulating the activity of Wnt/beta-catenin pathway. Tumour Biol 37: 1461-1469. http://doi.org/10.1007/s13277-015-4564-y

Gauthier AC, Liu J (2017) Epigenetics and Signaling Pathways in Glaucoma. Biomed Res Int 2017: 5712341. http://doi. org/10.1155/2017/5712341
Gong Q, Su G (2017) Roles of miRNAs and long noncoding RNAs in the progression of diabetic retinopathy. Biosci Rep 37. http://doi. org/10.1042/BSR20171157

Guo JU, Agarwal V, Guo H, Bartel DP (2014) Expanded identification and characterization of mammalian circular RNAs. Genome Biol 15: 409. http://doi.org/10.1186/s13059-014-0409-z

Hao F, Mou Y, Zhang L, Wang S, Yang Y (2018) LncRNA AFAP1AS1 is a prognostic biomarker and serves as oncogenic role in retinoblastoma. Biosci Rep 38. http://doi.org/10.1042/BSR20180384

Hu C, Liu S, Han M, Wang Y, Xu C (2018a) Knockdown of lncRNA XIST inhibits retinoblastoma progression by modulating the miR124/STAT3 axis. Biomed Pharmacother 107: 547-554. http://doi. org/10.1016/j.biopha.2018.08.020

Hu J, Wang L, Chen J, Gao H, Zhao W, Huang Y, Jiang T, Zhou J, Chen Y (2018b) The circular RNA circ-ITCH suppresses ovarian carcinoma progression through targeting miR-145/RASA1 signaling. Biochem Biophys Res Commun. http://doi.org/10.1016/j. bbrc. 2018.09 .060

Huang J, Li YJ, Liu JY, Zhang YY, Li XM, Wang LN, Yao J, Jiang Q, Yan B (2015) Identification of corneal neovascularization-related long noncoding RNAs through microarray analysis. Cornea 34: 580587. http://doi.org/10.1097/ICO.0000000000000389

Jeck WR, Sorrentino JA, Wang K, Slevin MK, Burd CE, Liu J, Marzluff WF, Sharpless NE (2013) Circular RNAs are abundant, conserved, and associated with ALU repeats. RNA 19: 141-157. http://doi.org/10.1261/rna.035667.112

Jia Y, Xiong K, Ren HX, Li WJ (2018) Identification of long noncoding RNA and mRNA expression in $\beta$ B2-crystallin knockout mice. Experimental and Therapeutic Medicine. http://doi.org/10.3892/ etm.2018.5949

Kaarniranta K, Salminen A (2009) NF-kappaB signaling as a putative target for omega-3 metabolites in the prevention of age-related macular degeneration (AMD). Exp Gerontol 44: 685-688. http://doi. org/10.1016/j.exger.2009.09.002

Kaneko H, Terasaki H (2017) Biological Involvement of MicroRNAs in Proliferative Vitreoretinopathy. Transl Vis Sci Technol 6: 5. http:// doi.org/10.1167/tvst.6.4.5

Kellner S, Burhenne J, Helm M (2010) Detection of RNA modifications. RNA Biol 7: 237-247

Khandelwal A, Bacolla A, Vasquez KM, Jain A (2015) Long non-coding RNA: A new paradigm for lung cancer. Mol Carcinog 54: 12351251. http://doi.org/10.1002/mc.22362

Kim J, Kim KM, Noh JH, Yoon JH, Abdelmohsen K, Gorospe M (2016) Long noncoding RNAs in diseases of aging. Biochim Biophys Acta 1859: 209-221. http://doi.org/10.1016/j.bbagrm.2015.06.013

Li CP, Wang SH, Wang WQ, Song SG, Liu XM (2017a) Long Noncoding RNA-Sox2OT Knockdown Alleviates Diabetes MellitusInduced Retinal Ganglion Cell (RGC) injury. Cell Mol Neurobiol 37: 361-369. http://doi.org/10.1007/s10571-016-0380-1

Li F, Wen X, Zhang H, Fan X (2016) Novel Insights into the Role of Long Noncoding RNA in Ocular Diseases. Int J Mol Sci 17: 478. http://doi.org/10.3390/ijms17040478

Li G, Song H, Chen L, Yang W, Nan K, Lu P (2017b) TUG1 promotes lens epithelial cell apoptosis by regulating miR-421/caspase-3 axis in age-related cataract. Exp Cell Res 356: 20-27. http://doi. org/10.1016/i.yexcr.2017.04.002

Li L, Chen W, Wang Y, Tang L, Han M (2018a) Long non-coding RNA H19 regulates viability and metastasis, and is upregulated in retinoblastoma. Oncol Lett 15: 8424-8432. http://doi.org/10.3892/ ol.2018.8385

Li LJ, Leng RX, Fan YG, Pan HF, Ye DQ (2017c) Translation of noncoding RNAs: Focus on lncRNAs, pri-miRNAs, and circRNAs. Exp Cell Res 361: 1-8. http://doi.org/10.1016/j.yexcr.2017.10.010

Li S, Wen D, Che S, Cui Z, Sun Y, Ren H, Hao J (2018b) Knockdown of long noncoding RNA 00152 (LINC00152) inhibits human retinoblastoma progression. Onco Targets Ther 11: 3215-3223. http:// doi.org/10.2147/OTT.S160428

Liu C, Li CP, Wang JJ, Shan K, Liu X, Yan B (2016) RNCR3 knockdown inhibits diabetes mellitus-induced retinal reactive gliosis. Biochem Biophys Res Commun 479: 198-203. http://doi.org/10.1016/j. bbrc.2016.09.032

Long Y, Wang X, Youmans DT, Cech TR (2017) How do lncRNAs regulate transcription? Sci $A d v$ 3: eaao2110. http://doi.org/10.1126/ sciadv.aao 2110

Ma WX, Huang XG, Yang TK, Yao JY (2018) Involvement of dysregulated coding and long noncoding RNAs in the pathogenesis of strabismus. Mol Med Rep 17: 7737-7745. http://doi.org/10.3892/ mmr.2018.8832

Memczak S, Jens M, Elefsinioti A, Torti F, Krueger J, Rybak A, Maier L, Mackowiak SD, Gregersen LH, Munschauer M, Loewer A, Ziebold U, Landthaler M, Kocks C, le Noble F, Rajewsky N (2013) Circular RNAs are a large class of animal RNAs with regulatory potency. Nature 495: 333-338. http://doi.org/10.1038/nature11928

Memczak S, Papavasileiou P, Peters O, Rajewsky N (2015) Identification and Characterization of Circular RNAs As a New Class of Pu- 
tative Biomarkers in Human Blood. PLoS One 10: e0141214. http:// doi.org/10.1371/journal.pone.0141214

Meola N, Pizzo M, Alfano G, Surace EM, Banfi S (2012) The long noncoding RNA Vax2os1 controls the cell cycle progression of photoreceptor progenitors in the mouse retina. $R N A$ 18: 111-123. http://doi.org/10.1261/rna.029454.111

Mercer TR, Dinger ME, Mattick JS (2009) Long non-coding RNAs: insights into functions. Nat Rev Genet 10: 155-159. http://doi. org/10.1038/nrg2521

Mercer TR, Mattick JS (2013) Structure and function of long noncoding RNAs in epigenetic regulation. Nat Struct Mol Biol 20: 300-307. http://doi.org/10.1038/nsmb.2480

Mercer TR, Qureshi IA, Gokhan S, Dinger ME, Li G, Mattick JS, Mehler MF (2010) Long noncoding RNAs in neuronal-glial fate specification and oligodendrocyte lineage maturation. BMC Neurosci 11: 14. http://doi.org/10.1186/1471-2202-11-14

Michalik KM, You X, Manavski Y, Doddaballapur A, Zornig M, Braun T, John D, Ponomareva Y, Chen W, Uchida S, Boon RA, Dimmeler S (2014) Long noncoding RNA MALAT1 regulates endothelial cell function and vessel growth. Circ Res 114: 1389-1397. http://doi. org/10.1161/CIRCRESAHA.114.303265

Nakano M, Ikeda Y, Tokuda Y, Fuwa M, Omi N, Ueno M, Imai K, Adachi H, Kageyama M, Mori K, Kinoshita S, Tashiro K (2012) Common variants in CDKN2B-AS1 associated with optic-nerve vulnerability of glaucoma identified by genome-wide association studies in Japanese. PLoS One 7: e33389. http://doi.org/10.1371/ journal.pone.0033389

Neely KA, Gardner TW (1998) Ocular neovascularization: clarifying complex interactions. Am J Pathol 153: 665-670. http://doi. org/10.1016/S0002-9440(10)65607-6

Pamudurti NR, Bartok O, Jens M, Ashwal-Fluss R, Stottmeister C, Ruhe L, Hanan M, Wyler E, Perez-Hernandez D, Ramberger E, Shenzis S, Samson M, Dittmar G, Landthaler M, Chekulaeva M, Rajewsky N, Kadener S (2017) Translation of CircRNAs. Mol Cell 66: 9-21 e27. http://doi.org/10.1016/j.molcel.2017.02.021

Pastori C, Wahlestedt C (2012) Involvement of long noncoding RNAs in diseases affecting the central nervous system. RNA Biol 9: 860870. http://doi.org/10.4161/rna.20482

Pradhan P, Upadhyay N, Tiwari A, Singh LP (2016) Genetic and epigenetic modifications in the pathogenesis of diabetic retinopathy: a molecular link to regulate gene expression. New Front Ophthalmol 2: 192-204. http://doi.org/10.15761/NFO.1000145

Qiu GZ, Tian W, Fu HT, Li CP, Liu B (2016) Long noncoding RNA-MEG3 is involved in diabetes mellitus-related microvascular dysfunction. Biochem Biophys Res Commun 471: 135-141. http://doi. org/10.1016/j.bbrc.2016.01.164

Rapicavoli NA, Poth EM, Blackshaw S (2010) The long noncoding RNA RNCR2 directs mouse retinal cell specification. BMC Dev Biol 10: 49. http://doi.org/10.1186/1471-213X-10-49

Rasool M, Malik A, Zahid S, Basit Ashraf MA, Qazi MH, Asif M, Zaheer A, Arshad M, Raza A, Jamal MS (2016) Non-coding RNAs in cancer diagnosis and therapy. Noncoding RNA Res 1: 69-76. http:// doi.org/10.1016/j.ncrna.2016.11.001

Ren GL, Zhu J, Li J, Meng XM (2018) Noncoding RNAs in acute kidney injury. J Cell Physiol. http://doi.org/10.1002/jcp.27203

Rinn JL, Chang HY (2012) Genome regulation by long noncoding RNAs. Annu Rev Biochem 81: 145-166. http://doi.org/10.1146/annurev-biochem-051410-092902

Robertson AG, Shih J, Yau C, Gibb EA, Oba J, Mungall KL, Hess JM, Uzunangelov V, Walter V, Danilova L, Lichtenberg TM, Kucherlapati M, Kimes PK, Tang M, Penson A, Babur O, Akbani R, Bristow CA, Hoadley KA, Iype L, Chang MT, Network TR, Cherniack AD, Benz C, Mills GB, Verhaak RGW, Griewank KG, Felau I, Zenklusen JC, Gershenwald JE, Schoenfield L, Lazar AJ, Abdel-Rahman MH, Roman-Roman S, Stern MH, Cebulla CM, Williams MD, Jager MJ, Coupland SE, Esmaeli B, Kandoth C, Woodman SE (2017) Integrative Analysis Identifies Four Molecular and Clinical Subsets in Uveal Melanoma. Cancer Cell 32: 204-220 e215. http://doi.org/10.1016/j.ccell.2017.07.003

Rong D, Sun H, Li Z, Liu S, Dong C, Fu K, Tang W, Cao H (2017) An emerging function of circRNA-miRNAs-mRNA axis in human diseases. Oncotarget 8: 73271-73281. http://doi.org/10.18632/oncotarget. 19154

Sallam T, Sandhu J, Tontonoz P (2018) Long Noncoding RNA Discovery in Cardiovascular Disease: Decoding Form to Function. Circ Res 122: 155-166. http://doi.org/10.1161/CIRCRESAHA.117.311802

Salzman J (2016) Circular RNA Expression: Its Potential Regulation and Function. Trends Genet 32: 309-316. http://doi.org/10.1016/j. tig.2016.03.002

Salzman J, Chen RE, Olsen MN, Wang PL, Brown PO (2013) Celltype specific features of circular RNA expression. PLoS Genet 9: e1003777. http://doi.org/10.1371/journal.pgen.1003777

Salzman J, Gawad C, Wang PL, Lacayo N, Brown PO (2012) Circular RNAs are the predominant transcript isoform from hundreds of human genes in diverse cell types. PLoS One 7: e30733. http://doi. org/10.1371/journal.pone.0030733
Shan K, Liu C, Liu BH, Chen X, Dong R, Liu X, Zhang YY, Liu B, Zhang SJ, Wang JJ, Zhang SH, Wu JH, Zhao C, Yan B (2017) Circular Noncoding RNA HIPK3 Mediates Retinal Vascular Dysfunction in Diabetes Mellitus. Circulation 136: 1629-1642. http://doi. org/10.1161/CIRCULATIONAHA.117.029004

Shang Y (2018) LncRNA THOR acts as a retinoblastoma promoter through enhancing the combination of $\mathrm{c}-\mathrm{myc} \mathrm{mRNA}$ and IGF2BP1 protein. Biomed Pharmacother 106: 1243-1249. http://doi. org/10.1016/j.biopha.2018.07.052

Shen Y, Dong LF, Zhou RM, Yao J, Song YC, Yang H, Jiang Q, Yan B (2016) Role of long non-coding RNA MIAT in proliferation, apoptosis and migration of lens epithelial cells: a clinical and in vitro study. J Cell Mol Med 20: 537-548. http://doi.org/10.1111/ jcmm. 12755

Sheng L, Wu J, Gong X, Dong D, Sun X (2018) SP1-induced upregulation of lncRNA PANDAR predicts adverse phenotypes in retinoblastoma and regulates cell growth and apoptosis in vitro and in vivo. Gene 668: 140-145. http://doi.org/10.1016/j.gene.2018.05.065

Shiga Y, Nishiguchi KM, Kawai Y, Kojima K, Sato K, Fujita K, Takahashi M, Omodaka K, Araie M, Kashiwagi K, Aihara M, Iwata T, Mabuchi F, Takamoto M, Ozaki M, Kawase K, Fuse N, Yamamoto M, Yasuda J, Nagasaki M, Nakazawa T, Japan Glaucoma Society Omics G (2017) Genetic analysis of Japanese primary open-angle glaucoma patients and clinical characterization of risk alleles near CDKN2B-AS1, SIX6 and GAS7. PLoS One 12: e0186678. http:// doi.org/10.1371/journal.pone.0186678

Su S, Gao J, Wang T, Wang J, Li H, Wang Z (2015) Long non-coding RNA BANCR regulates growth and metastasis and is associated with poor prognosis in retinoblastoma. Tumour Biol 36: 7205-7211. http://doi.org/10.1007/s13277-015-3413-3

Sun M, Kraus WL (2015) From discovery to function: the expanding roles of long noncoding RNAs in physiology and disease. Endocr Rev 36: 25-64. http://doi.org/10.1210/er.2014-1034

Taheri M, Omrani MD, Ghafouri-Fard S (2018) Long non-coding RNA expression in bladder cancer. Biophys Rev 10: 1205-1213. http://doi.org/10.1007/s12551-017-0379-y

Tan GC (2014) The History of RNAi and MicroRNA Discovery. Med \& Health 9: 2

Tang Y, Zhou T, Yu X, Xue Z, Shen N (2017) The role of long noncoding RNAs in rheumatic diseases. Nat Rev Rheumatol 13: 657-669. http://doi.org/10.1038/nrrheum.2017.162

Tessier CR, Doyle GA, Clark BA, Pitot HC, Ross J (2004) Mammary tumor induction in transgenic mice expressing an RNA-binding protein. Cancer Res 64: 209-214

Wan P, Su W, Zhuo Y (2017) Precise long non-coding RNA modulation in visual maintenance and impairment. J Med Genet 54: 450459. http://doi.org/10.1136/jmedgenet-2016-104266

Wang C, Wang L, Ding Y, Lu X, Zhang G, Yang J, Zheng H, Wang H, Jiang Y, Xu L (2017a) LncRNA Structural Characteristics in Epigenetic Regulation. Int J Mol Sci 18. http://doi.org/10.3390/ ijms18122659

Wang JJ, Shan K, Liu BH, Liu C, Zhou RM, Li XM, Dong R, Zhang SJ, Zhang SH, Wu JH, Yan B (2018a) Targeting circular RNAZRANB1 for therapeutic intervention in retinal neurodegeneration. Cell Death Dis 9: 540. http://doi.org/10.1038/s41419-018-0597-7

Wang M, Chen B, Ru Z, Cong L (2018b) CircRNA circ-ITCH suppresses papillary thyroid cancer progression through miR-22-3p/ CBL/beta-catenin pathway. Biochem Biophys Res Commun 504: 283288. http://doi.org/10.1016/j.bbrc.2018.08.175

Wang S, Liu J, Yang Y, Hao F, Zhang L (2018c) PlncRNA-1 is overexpressed in retinoblastoma and regulates retinoblastoma cell proliferation and motility through modulating CBR3. IUBMB Life. http://doi.org/10.1002/iub.1886

Wang Y, Wang J, Wei LJ, Zhu DM, Zhang JS (2017b) Biological function and mechanism of lncRNA-MEG3 in Tenon's capsule fibroblasts proliferation: By MEG3-Nrf2 protein interaction. Biomed Pharmacother 87: 548-554. http://doi.org/10.1016/j.biopha.2016.12.040

Wang Y, Wang Z (2015) Efficient backsplicing produces translatable circular mRNAs. RNA 21: 172-179. http://doi.org/10.1261/ rna.048272.114

Xu XD, Li KR, Li XM, Yao J, Qin J, Yan B (2014) Long non-coding RNAs: new players in ocular neovascularization. Mol Biol Rep 41: 4493-4505. http://doi.org/10.1007/s11033-014-3320-5

Xu Y, Xing YQ (2018) Long non-coding RNA GAS5 contributed to the development of glaucoma via regulating the TGF-beta signaling pathway. Eur Rev Med Pharmacol Sci 22: 896-902. http://doi. org/10.26355/eurrev 201802 14367

Yan B, Wang Z (2012) Long noncoding RNA: its physiological and pathological roles. DNA Cell Biol 31 (Suppl 1): S34-S41. http://doi. org/10.1089/dna.2011.1544

Yan B, Yao J, Tao ZF, Jiang Q (2014) Epigenetics and ocular diseases: from basic biology to clinical study. J Cell Physiol 229: 825-833. http://doi.org/10.1002/jcp.24522

Yang C, Yuan W, Yang X, Li P, Wang J, Han J, Tao J, Li P, Yang H, Lv Q, Zhang W (2018a) Circular RNA circ-ITCH inhibits bladder cancer progression by sponging $\mathrm{miR}-17 / \mathrm{miR}-224$ and regulating 
p21, PTEN expression. Mol Cancer 17: 19. http://doi.org/10.1186/ s12943-018-0771-7

Yang G, Fu Y, Lu X, Wang M, Dong H, Li Q (2018b) LncRNA HOTAIR/miR-613/c-met axis modulated epithelial-mesenchymal transition of retinoblastoma cells. J Cell Mol Med. http://doi. org/10.1111/jcmm.13796

Yang S, Yao H, Li M, Li H, Wang F (2016) Long Non-Coding RNA MALAT1 Mediates Transforming Growth Factor Beta1-Induced Epithelial-Mesenchymal Transition of Retinal Pigment Epithelial Cells. PLoS One 11: e0152687. http://doi.org/10.1371/journal. pone.0152687

Yang Y, Fan X, Mao M, Song X, Wu P, Zhang Y, Jin Y, Yang Y, Chen LL, Wang Y, Wong CC, Xiao X, Wang Z (2017) Extensive translation of circular RNAs driven by $\mathrm{N}(6)$-methyladenosine. Cell Res 27: 626-641. http://doi.org/10.1038/cr.2017.31

Yang Y, Pan JJ, Zhou XG, Zhou XY, Cheng R (2018c) Differentially expressed miRNAs in premature infants with retinopathy-a bioinformatics analysis. Int J Opbthalmol 11: 773-779. http://doi. org/10.18240/ijo.2018.05.09

Yonekawa Y, Miller JW, Kim IK (2015) Age-Related Macular Degeneration: Advances in Management and Diagnosis. J Clin Med 4: 343359. http://doi.org/10.3390/jcm4020343

Young TL, Matsuda T, Cepko CL (2005) The noncoding RNA taurine upregulated gene 1 is required for differentiation of the murine retina. Curr Biol 15: 501-512. http://doi.org/10.1016/j.cub.2005.02.027

Yue Y, Zhang J, Yang L, Liu S, Qi J, Cao Q, Zhou C, Wang Y, Kijlstra A, Yang P, Hou S (2018) Association of Long Noncoding RNAs Polymorphisms With Ankylosing Spondylitis, Vogt-Koyanagi-Harada Disease, and Behcet's Disease. Invest Ophthalmol Vis Sci 59: 1158-1166. http://doi.org/10.1167/iovs.17-23247

Zhang HD, Jiang LH, Hou JC, Zhou SY, Zhong SL, Zhu LP, Wang DD, Yang SI, He YJ, Mao CF, Yang Y, Wang JY, Zhang Q, Xu HZ, Yu DD, Zhao JH, Tang JH, Ji ZL (2018) Circular RNA hsa_circ_0072995 promotes breast cancer cell migration and invasion through sponge for miR-30c-2-3p. Epigenomics 10: 1229-1242. http://doi.org/10.2217/epi-2018-0002
Zhang J, Chen M, Chen J, Lin S, Cai D, Chen C, Chen Z (2017a) Long non-coding RNA MIAT acts as a biomarker in diabetic retinopathy by absorbing miR-29b and regulating cell apoptosis. Biosci Rep 37. http://doi.org/10.1042/BSR20170036

Zhang SJ, Chen X, Li CP, Li XM, Liu C, Liu BH, Shan K, Jiang Q, Zhao C, Yan B (2017b) Identification and Characterization of Circular RNAs as a New Class of Putative Biomarkers in Diabetes Retinopathy. Invest Ophthalmol Vis Sci 58: 6500-6509. http://doi. org/10.1167/iovs.17-22698

Zhang XO, Wang HB, Zhang Y, Lu X, Chen LL, Yang L (2014) Complementary sequence-mediated exon circularization. Cell 159: 134-147. http://doi.org/10.1016/j.cell.2014.09.001

Zhang Y, Cai S, Jia Y, Qi C, Sun J, Zhang H, Wang F, Cao Y, Li X (2017c) Decoding Noncoding RNAs: Role of MicroRNAs and Long Noncoding RNAs in Ocular Neovascularization. Theranostics 7: 3155-3167. http://doi.org/10.7150/thno.19646

Zhang Y, Li Y, Wang Q, Zhang X, Wang D, Tang HC, Meng X, Ding $\mathrm{X}(2017 \mathrm{~d})$ Identification of an IncRNAmiRNAmRNA interaction mechanism in breast cancer based on bioinformatic analysis. Mol Med Rep 16: 5113-5120. http://doi.org/10.3892/mmr.2017.7304

Zhang Y, Zhang XO, Chen T, Xiang JF, Yin QF, Xing YH, Zhu S, Yang L, Chen LL (2013) Circular intronic long noncoding RNAs. Mol Cell 51: 792-806. http://doi.org/10.1016/j.molcel.2013.08.017

Zhong Y, Du Y, Yang X, Mo Y, Fan C, Xiong F, Ren D, Ye X, Li C, Wang Y, Wei F, Guo C, Wu X, Li X, Li Y, Li G, Zeng Z, Xiong W (2018) Circular RNAs function as ceRNAs to regulate and control human cancer progression. Mol Cancer 17: 79. http://doi. org/10.1186/s12943-018-0827-8

Zhou RM, Wang XQ, Yao J, Shen Y, Chen SN, Yang H, Jiang Q, Yan B (2015) Identification and characterization of proliferative retinopathy-related long noncoding RNAs. Biochem Biophys Res Commun 465: 324-330. http://doi.org/10.1016/j.bbrc.2015.07.120

Zhu W, Meng YF, Xing Q, Tao JJ, Lu J, Wu Y (2017) Identification of lncRNAs involved in biological regulation in early age-related macular degeneration. Int J Nanomedicine 12: 7589-7602. http://doi. org/10.2147/IJN.S140275 